\title{
Rancang Bangun Pengamat Parameter Cuaca Menggunakan Komunikasi Nir Kabel
}

\author{
Vadhya Wiendyas Gandoria ${ }^{1}$, V. Vekky R. Repi ${ }^{1 *}$, Agus Wibowo ${ }^{2}$ \\ ${ }^{1}$ Program Studi Teknik Fisika, Universitas Nasional, Jakarta \\ ${ }^{2}$ Program Studi Teknik Elektro, Universitas Nasional, Jakarta \\ *Korespondensi penulis: vekky2000@gmail.com
}

\begin{abstract}
Abstrak. Automatic Weather Sation (AWS) sampai saat ini belum ada produksi dalam negeri, dengan demikian dibutuhkan penelitian lebih lanjut menyangkut AWS yang dapat mendeteksi parameter cuaca. Maka dibangunlah sistim pengamat parameter cuaca ini, yang dilengkapi dengan 4 buah sensor, yaitu: DHT22 untuk mengukur suhu dan kelembaban, BMP180 untuk mengukur tekanan udara, LDR untuk mengukur penguatan cahaya (Iluminasi), serta opto-interrupt-device untuk mengukur kecepatan angin dengan kondisi cuaca yang diamati pada suatu titik tempat. Data sensor akan diolah dalam mikrokontroler Arduino, lalu ditampilkan melalui VB.Net dan data akan tersimpan ke dalam database MySQL. Akses pengiriman data menggunakan wireless NRF24L01 yang dapat berfungsi sebagai transceiver. Sistim yang dirancang akan dibandingkan dengan AWS milik Universitas Nasional. Dengan hasil pengujian tiap parameter diantaranya suhu error maximum $1.76 \%$, kelembaban error maximum $4.3 \%$, iluminasi error rata-rata $1.5 \%$, tekanan udara error maximum $0.0099 \%$, kecepatan angin erorr maximum $21.6 \%$.
\end{abstract}

Kata kunci: Sistim pemantau cuaca, wireless communication, sistim telemetri, automatic weather station.

\begin{abstract}
Automatic Weather Station (AWS) until now there is no domestic production, thus more research is needed concerning AWS that can detect weather parameters. It built a analysts system meteorological parameters, which is equipped with four sensors, that is DHT22 to measure temperature and humidity, BMP180 for measuring air pressure, LDR to measure the gain of light (Illumination), and opto-interrupt-device to measure wind speed with weather conditions observed at a point where. Sensor data will be processed in the microcontroller Arduino, then displayed through VB.Net and data will be stored in MySQL database. Access wireless data transmission using NRF24L01 which can function as a transceiver. The system is designed to be compared with AWS belonging to the National University. The results for each parameter as follows $1.76 \%$ maximum error temperature, humidity $4.3 \%$ maximum error, error Illumination average of $-1.5 \%$, the air pressure maximum error $0.0099 \%$, maximum wind speed erorr $21.6 \%$.
\end{abstract}

Keywords: Weather monitoring system, wireless communication, telemetry system, automatic weather station.

\section{PENDAHULUAN}

Cuaca merupakan salah satu faktor penting bagi kehidupan manusia yang sangat berpengaruh di bidang pelayaran, pertanian, penerbangan dan komunikasi. Cuaca dapat mempengaruhi baik tidaknya sinyal komunikasi pada waktu tertentu. Parameter yang dapat diamati pada cuaca antara lain, suhu udara, kelembaban udara, kecepatan angin, tekanan udara dan curah hujan. Dalam pengambilan data parameter cuaca, stasiun cuaca BMKG menggunakan dua metode yaitu konvensional dan modern (bantuan sistem otomasi). Pengambilan dan penyajian data pada stasiun cuaca di Indonesia umumnya masih menggunakan cara konvensional, dimana pencatatan datanya tergantung oleh manusia (pengamat). Dalam metode modern pengembangan dari sistem pemantauan cuaca menggunakan Automatic Weather Station (AWS), yaitu sistem cuaca otomatis 
dengan sistem terpadu yang merupakan penggabungan dari beberapa sensor yang digunakan untuk memantau parameter-parameter cuaca yang ada. Automatic Weather Station telah lama dikembangkan di negara maju. AWS digunakan untuk memantau cuaca oleh instansi pemerintahhan dan saat ini masih merupakan produk buatan luar negeri dengan harga relatif mahal, sehingga masih sangat terbatas digunakan di Indonesia, dan hingga saat ini belum ada AWS produksi dalam negeri [1].

Oleh karena itu diperlukan adanya penelitian lebih lanjut mengenai sistim pengamat atau pendeteksi parameter cuaca yang mudah dioperasikan sebagai penunjang dalam pengamatan parameter cuaca dengan harga yang terjangkau. Dalam penelitian ini penulis akan merancang suatu sistim pengamatan parameter cuaca yang menggunakan beberapa sensor dengan sistim telemetri wireless, berbasis Arduino UNO dengan menggunakan interface pc berbasis Visual Basic. Net. Cuaca merupakan keadaan udara pada saat waktu tertentu, di suatu wilayah tertentu yang relatif sempit, dan pada jangka waktu yang singkat. Cuaca terbentuk dari gabungan beberapa unsur cuaca, dan cuaca memiliki jangka waktu hanya beberapa jam. Misalnya pagi, atau siang sore hari dan keadaannya bisa berbeda-beda untuk setiap tempat serta setiap jamnya [2].

Di Indonesia keadaan cuaca selalu diprakirakan untuk jangka waktu sekitar 24 jam pada daerah tertentu (misalnya provinsi atau kabupaten/kota) melalui prakiraan cuaca hasil analisis BMKG, sedangkan negara maju perubahan cuaca sudah diprakirakan setiap jam dan sangat akurat. Analisis cuaca disesuaikan sesuai dengan skala ruang dan waktu. Skala waktu meliputi antar tahun sampai lebih besar, tahunan (annual), musiman, intramusiman, harian, jam sampai yang lebih kecil. Beberapa unsur yang mempengaruhi keadaan cuaca pada suatu daerah, antara lain temperatur, kelembaban, tekanan udara, curah hujan, dan kecepatan angin [3].

Temperatur merupakan keadaan panas atau dinginnya udara. Kelembaban udara menyatakan banyaknya uap air di dalam udara. Di udara terdapat uap air yang berasal dari penguapan samudra sebagai sumber utama. Semakin tinggi suhu udara, maka akan semakin banyak uap air yang dapat dikandung dalam udara atau saturation-point humidity $(\mathrm{SH})$. Kelembaban udara relatif $(\mathrm{RH})$ merupakan bentuk yang menunjukkan perbandingan jumlah uap air dalam udara (kelembaban absolut / $\mathrm{AH}$ ) dengan jumlah uap air maksimum yang dapat dikandung oleh udara tersebut dalam suhu yang sama dan dinyatakan dalam persen (\%). Sehingga apabila suhu semakin tinggi (panas) maka kelembaban relatif akan semakin berkurang. [4]. Oleh karena itu, tekanan udara berbeda menurut ketinggian tempat (altitude) dan lintang, maka sebagai standar digunakan tinggi permukaan laut dan lintang 45 derajat belahan bumi utara (BBU) yang dinyatakan dengan tekanan udara normal [3]. Adanya perbedaan tekanan udara akan mengakibatkan terjadinya pergerakan udara yang arahnya secara vertikal atau horizontal. Pergerakan udara secara horizontal atau hampir horizontal disebut angin, sedangkan secara vertikal (keatas atau kebawah) disebut arus udara. Angin dapat bergerak horizontal atau vertikal dengan kecepatan bervariasi dan berfluktuasi dinamis.

Sensor DHT22 dari Aosong Electronics mampu melakukan pengukuran suhu dan kelembaban secara bersamaan dengan keluaran digital. Sensor suhu dan kelembaban ini memiliki kelebihan sebagai berikut [5]:

- Keluaran berupa sinyal digital dengan konversi dan perhitungan dilakukan oleh MCU 8-bit terpadu;

- Sensor terkalibrasi secara akurat dengan kompensasi suhu di ruang penyesuaian dengan nilai koefisien kalibrasi tersimpan dalam memori OTP terpadu,dan lebih akurat dan presisi dibandingkan sensor DHT-11;

- Rentang pengukuran suhu dan kelembapan yang lebih lebar sehingga mampu mentransmisikan sinyal keluaran melewati kabel yang panjang hingga 20 meter sehingga tepat untuk ditempatkan dimana saja.

Sensor yang digunakan pada pengukuran tekanan udara adalah sensor BMP180, yang merupakan sensor tekanan barometrik (digital barometric pressure sensor) yang berkinerja sangat tinggi yang dapat diaplikasikan pada berbagai perangkat bergerak, 
seperti smart phone, komputer tablet, perangkat diluar ruangan, dan peralatan olah raga portabel. BMP180 adalah penyempurnaan fungsi BMP085 dengan banyak peningkatan yang signifikan, seperti ukuran yang lebih kecil, lebih hemat energi, konsumsi energi sangat rendah kurang dari $3 \mu \mathrm{A}$, dan penambahan antarmuka digital yang baru. Kelebihan lain dari sensor ini adalah kinerjanya yang sangat stabil terlepas dari pasokan tegangan yang digunakan. Dengan ketinggian noise yang cukup rendah, yaitu hanya $0.25 \mathrm{~m}$ dengan waktu konversi yang sangat cepat. Selain itu, sensor ini memiliki akurasi relatif $=950 \mathrm{~s} / \mathrm{d} 1050 \mathrm{hPa}$ (hectopascal) atau $\pm 0.12 \mathrm{hPa}$ pada $25^{\circ} \mathrm{C}$ dan $700 \mathrm{~s} / \mathrm{d} 900$ $\mathrm{hPa}$ atau $\pm 0.12 \mathrm{hPa}$ pada saat $25 \mathrm{~s} / \mathrm{d} 40^{\circ} \mathrm{C}$.

Opto Interrupt Device (OID) adalah sensor yang digunakan untuk membaca sinyal keluaran yang dihasilkan dari putaran piringan (yang titik pusatnya terhubung dengan baling-baling lingkaran berbentuk mangkuk) pada saat terkena angin. OID merupakan sensor yang terdiri dari 2 bagian yaitu transmitter dan receiver, yaitu antara bagian cahaya dengan bagian deteksi sumber cahaya terpisah. Photo-interrupter mempunyai prinsip kerja yang hampir sama dengan optocoupler. Akan tetapi, photo-interrupter dapat digunakan untuk mendeteksi ada tidaknya halangan yang berada diantara transmitter dan receiver [6]. Pada transmitter dibangun dari sebuah LED inframerah. Jika dibandingkan dengan menggunakan LED biasa, sedangkan pada bagian receiver dibangun dengan dasar komponen phototransistor. Phototransistor .Photo-interrupter bekerja dengan logika seperti berikut :

- Tidak ada halangan

Saat tidak ada halangan, cahaya inframerah yang dipancarkan oleh IR LED (transmitter) dapat diterima oleh phototransistor (receiver). Sehingga output photointerrupter akan berlogika HIGH, "1"

- Ada halangan

Saat ada halangan, cahaya inframerah yang dipancarkan oleh IR LED (transmitter) tidak dapat diterima oleh phototransistor (receiver). Sehingga output photointerrupter akan berlogika LOW, "0"

Sensor yang digunakan untuk mendeteksi cahaya adalah Light Dependent Resistor (LDR). Sensor ini digunakan karena memiliki spektrum respons yang tidak linier, tetapi dapat digunakan untuk pengukuran iluminasi untuk ruangan yang berbeda-beda [7]. Sebuah light dependent resistor (LDR) terdiri dari sebuah piringan bahan semikonduktor dengan dua buah elektroda pada permukaannya. Pada umumnya LDR terbuat dari bahan $\mathrm{CdS}, \mathrm{CdSe}, \mathrm{PbS}$, dan $\mathrm{Bi}_{2} \mathrm{Se}_{3}$. Dalam gelap atau dibawah cahaya yang redup, bahan piringan hanya menghasilkan elektron bebas dalam jumlah yang relatif sangat kecil untuk mengalirkan muatan listrik. Hal ini berarti bahwa bahan bersifat sebagai konduktor yang buruk untuk mengalirkan arus listrik atau bisa disebut juga LDR memiliki nilai resistansi yang besar pada saat cahaya redup. Sedangkan dalam cahaya yang terang, lebih banyak elektron yang lepas dari atom-atom bahan semikonduktor tersebut, sehingga lebih banyak elektron bebas untuk mengangkut muatan listrik. Artinya pada saat cahaya terang, LDR menjadi konduktor yang baik atau bisa disebut juga LDR memiliki resistansi yang kecil pada saat cahaya terang.

\section{PERANCANGAN ALAT}

Perancangan alat pada sistem ini secara garis besar terbagi dua bagian, yaitu bagian perangkat keras dan bagian perangkat lunak. Dan akan dibahas mengenai perancangan dan pembuatan perangkat keras serta perangkat lunak pendukungnya. Dalam alat pendeteksi ini menggunakan interface VB.NET 2010 sebagai tampilannya dan data akan disimpan dalam database. Alat ini ditunjang dengan perangkat keras dan perangkat lunak dengan spesifikasi perangkat keras yang digunakan berupa arduino UNO, sensor DHT22, Sensor BMP180, Anemometer, Sensor LDR, Laptop dengan processor Intel(R) Core(TM) i3-2370M, RAM 4GB, Wireless NRF24101, Baterai AKI 7.25-7.45V. Sementara perangkat lunak yang digunakan adalah Visual Basic.Net, database MySQL 
Pada gambar 1 merupakan diagram blok perancangan sistem penelitian ini secara keseluruhan. Masukan yang berupa unsur-unsur cuaca yang akan terdeteksi oleh masingmasing sensor baik data yang berupa analog maupun digital.

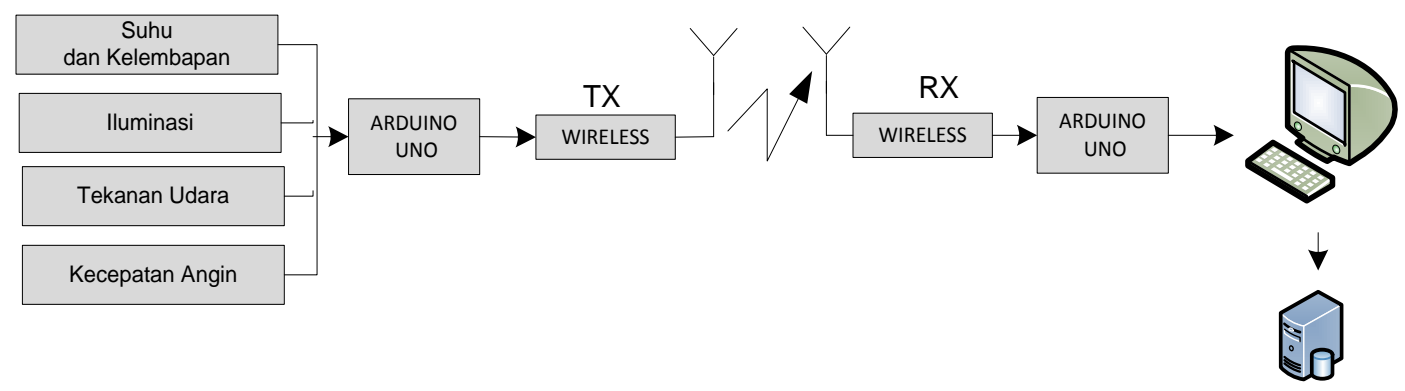

GAMBAR 1. Diagram Blok Alat Pendeteksi Cuaca

Selanjutnya data akan masuk dalam bentuk sinyal digital dan analog ke Arduino Uno yang berada di bagian transmitter dan data akan dibaca supaya didapatkan suatu nilai ukur dari masing-masing parameter. Dan data nilai yang terukur tersebut akan dikirimkan melalui wireless transmitter ke wireless receiver. Setelah wireless receiver menerima data dari tiap-tiap sensor, data akan diterima oleh Arduino Uno pada bagian receiver. Dan selanjutnya data akan dapat ditampilkan pada VB.Net sebagai penampil pada PC dan data akan langsung tersimpan pada database MySQL pada waktu yang telah ditentukan.

\section{HASIL DAN PEMBAHASAN}

Pada gambar 2 dapat dilihat hasil pembacaan sensor DHT22 dan AWS, pergerakannya masih tidak linier. Pada saat suhu AWS standar mengalami kestabilan atau nilai yang konstan, suhu pada alat yang dirancang mengalami kenaikan dan penurunan. Namun nilai selisih pembacaan dari DHT22 dengan AWS lumayan kecil mulai $0 \mathrm{~s} / \mathrm{d} 0.5^{\circ} \mathrm{C}$ saja dengan nilai error maximum $1.76 \%$ dan error minimum $0 \%$.

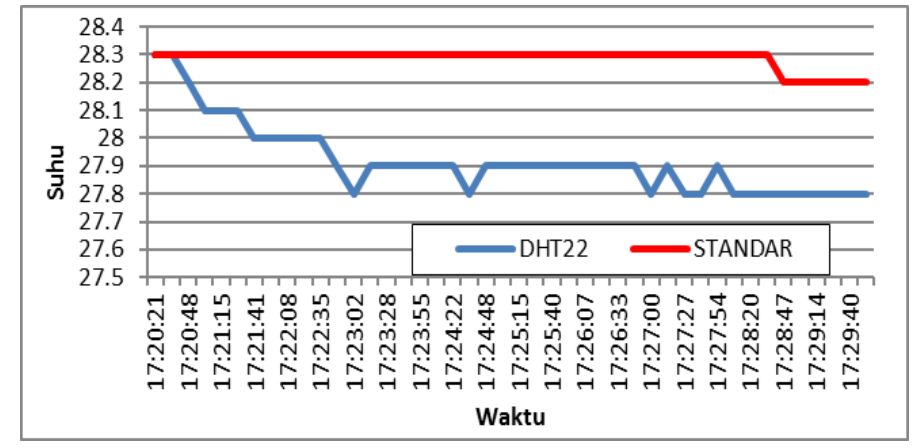

GAMBAR 2. Hasil pembacaan data uji dari sensor Suhu.

Sedangkan pada gambar 3 merupakan data pada saat pengambilan data di Laboratorium Teknik Fisika, Universitas Nasional Jakarta, data yang di bahas merupakan data tanggal 28 Januari 2018 pada pukul 12.00 siang s/d pukul 16.00 sore hari.

Pada pukul 12:00 temperatur cenderung memanas daripada pukul 13:00 s/d pukul 16:00 ini masih dikatakan logis karena temperatur udara meningkat pada saat matahari berada diatas kepala kita dan temperatur menurun pada saat mulai sore hari.

Gambar 4 adalah hasil pembacaan alat untuk data kelembaban. Pengujian alat dianalisa bahwa pembacaan sensor DHT22 pada pengukuran kelembaban adalah linier. Pada saat AWS standar menunjukan nilai yang konstan tidak berubah, yaitu pada pukul 17:20 s/d 17:22 (79\%) sistem yang dirancang juga menunjukan nilai yang konstan yaitu $82 \%$ 82.6\% dengan selisih pembacaan 3.6\%. dan pada pukul 17:23 s/d 17:29 AWS standar menunjukan nilai $80 \%$ dan alat rancangan menunjukan nilai $83 \%-83.5 \%$ dengan selisih 
pembacaan $3.5 \%$. Dengan nilai error maximum $4.3 \%$ dan error minimum $2.5 \%$ dari selisih pembacaan.

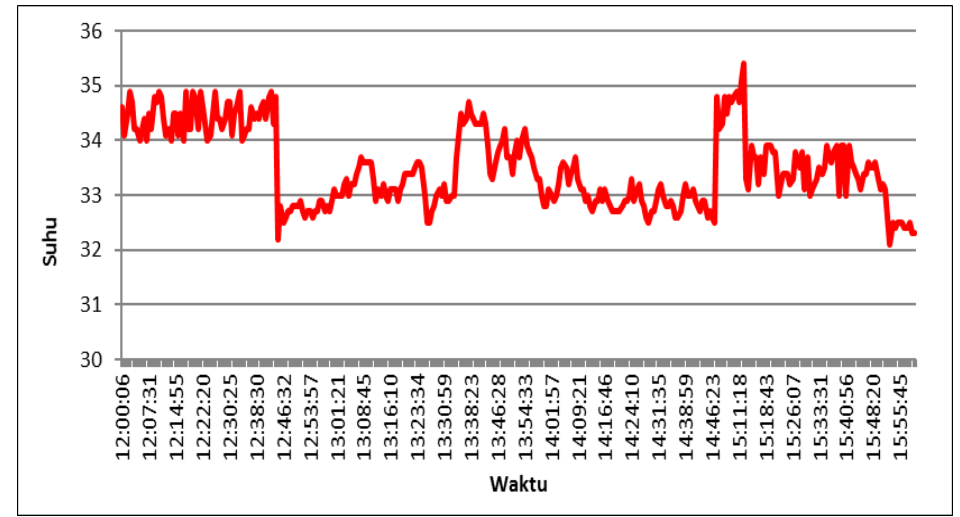

GAMBAR 3. Fluktuasi suhu saat pengambilan data pukul 12.00 hingga 16.00

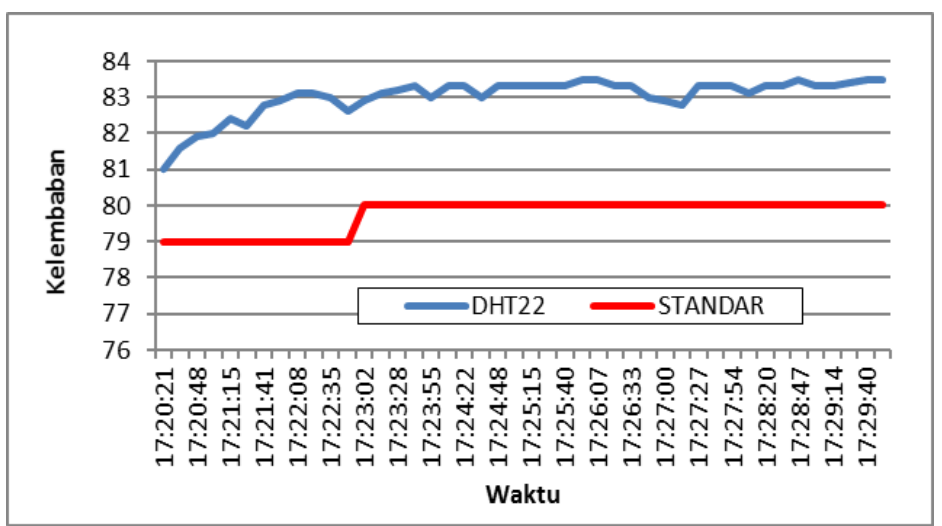

GAMBAR 4. Hasil pembacaan data ujian dengan sensor kelembaban

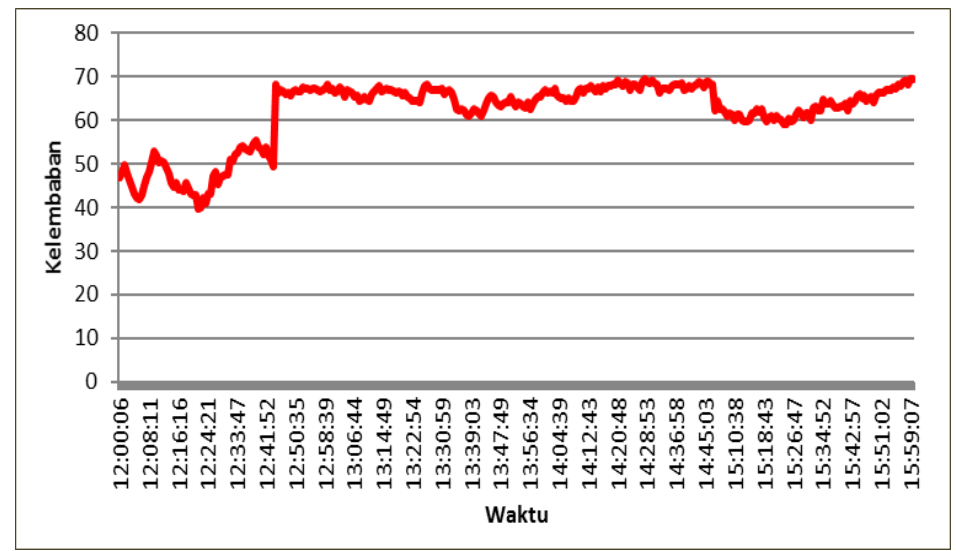

GAMBAR 5. Hasil pembacaan data uji sensor suhu

Pada gambar 5 adalah pembacaan sensor suhu data pada saat pengambilan data pada pukul 12:00 kelembaban cenderung lebih rendah daripada pukul 13:00 s/d pukul 16:00 ini masih dikatakan logis karena kelembaban meningkat pada saat temperatur menurun saat mulai sore hari.

Pada gambar 6 adalah nilai error yang dihasilkan masih cukup besar dimana error terbesar yang diperoleh adalah 5.3\% ini merupakan nilai yang cukup besar, besar untuk suatu penunjukan alat ukur. Dari kesalahan penunjukan juga memiliki nilai cukup besar dengan nilai 2.95 lux. Pada gambar 7 adalah gambar data pada saat pengambilan data iluminasi yang dilakukan pada pukul 12.00 . 


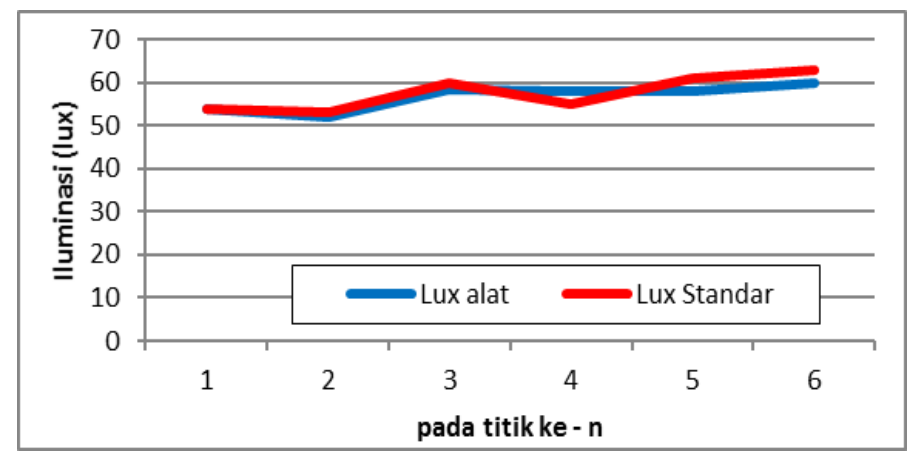

GAMBAR 6. Hasil Pengujian Iluminasi

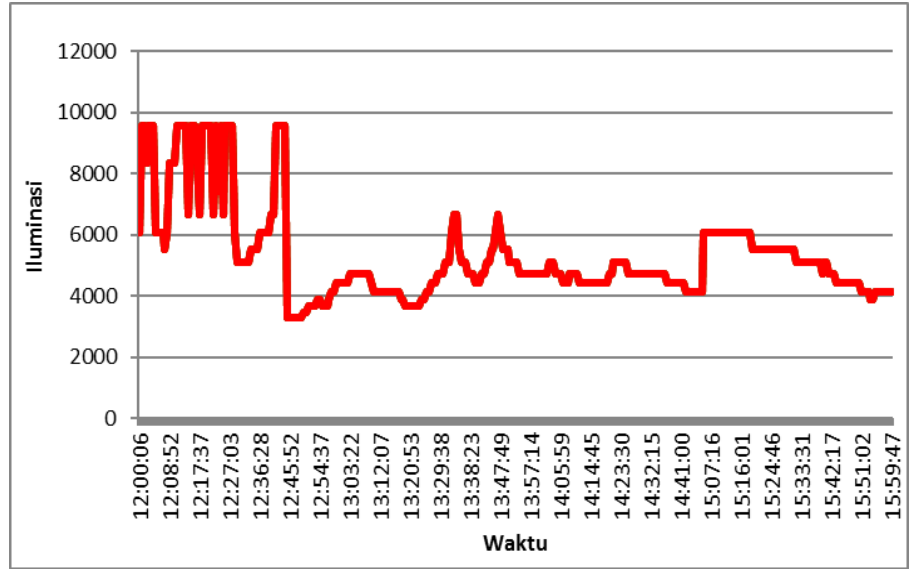

GAMBAR 7. Hasil pembacaan data sensor iluminasi pada pukul 12.00

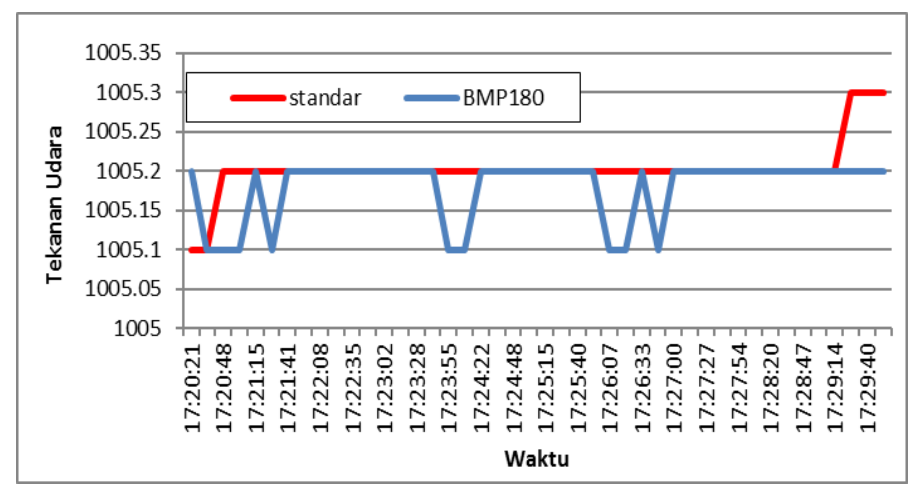

GAMBAR 8. Hasil pembacaan data sensor ujian tekanan udara

Pada pukul 12:00 Iluminasi cenderung lebih tinggi daripada pukul 13:00 s/d pukul 16:00 ini masih dikatakan logis karena penguatan cahaya meningkat pada saat matahari berada tepat diatas kepala sedangkan pada pukul 13:00 matahari mulai bergerak ke barat.

Pada gambar 8 adalah pembaacan sensor tekanan udara, terlihat dari pembacaan alat uji tidak linier, pada saat AWS standar pergerakkannya konstan yaitu $1005.2 \mathrm{hPa}$ sensor BMP180 juga menunjukan pergerakan kenaikan dan penurunan sesaat dengan nilai 1005.1 hPa sampai 1005.3 hPa. Namun nilai erorr dari selisih pembacaan terbesar $0.0099 \%$ dan terkecil $-0.0099 \%$. Pada gambar 9 adalah hasil pembacaan data tekanan udara dengan menggunakan alat uji.

Pada pukul 12:00 Tekanan udara terlihat stabil yaitu $\pm 1006 \mathrm{hPa}$ dan mengalami kenaikan pada pukul 12:50 sekitar $\pm 1007 \mathrm{hPa}$ dan mengalami penurunan kembali hingga pukul 16.00 tetapi penurunan masih di rentang $\pm 1006 \mathrm{hPa}$. Ini masih logis karena perubahan tidak terlalu jauh, dimana tekanan udara berubah sesuai dengan keadaan tingginya. 


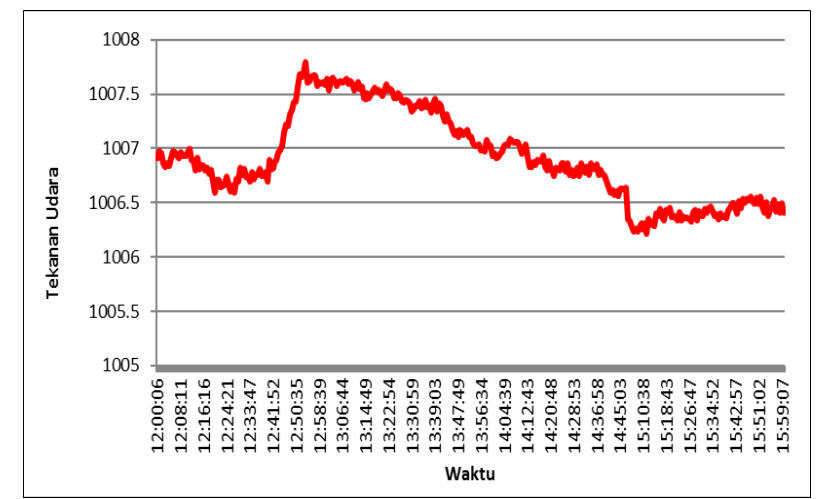

GAMBAR 9. Hasil pembacaan data uji sensor tekanan udara pada pukul 12.00

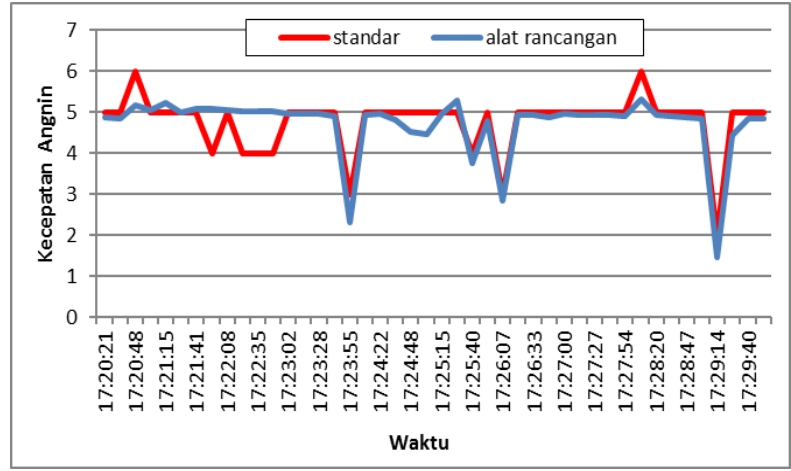

GAMBAR 10. Hasil pembacaan alat uji sensor dan alat standar pada pengujian kecepatan angin.

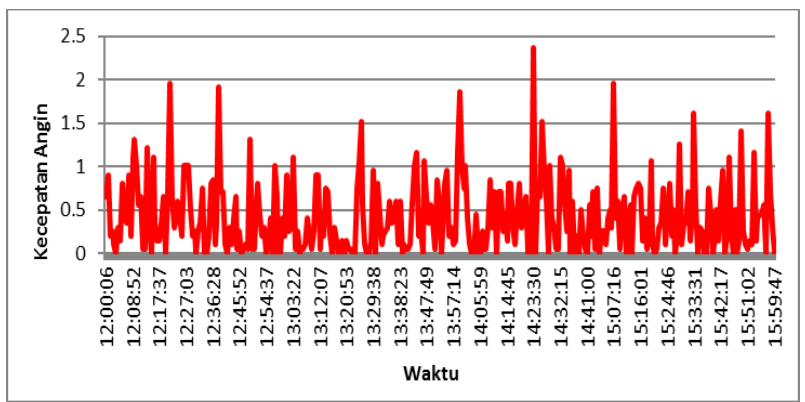

GAMBAR 11. Hasil pembacaan alat uji sensor kecepatan angin.

Dapat lihat pada gambar 10 adalah data pengujian penunjukkan anemometer yang di rancang linier dengan penunjunkan AWS standar. Pada saat pergerakkan AWS standar mengalami kenaikan penunjukan anemometer juga mengalami kenaikan dan pada saat pergerakkan AWS standar mengalami penurunan, anemometer tersebut juga mengalami penurunan dengan nilai kenaikan standar 5 knots dan alat standar 4.88 knots dan nilai penurunan AWS standar 2 knots, sedangkan anemometer 1.45 knots. Dengan nilai error maksimum 21.6\% dan error minimum -26.7\% dari selisih pembacaan.

Pada gambar 11 adalah gambar data pada saat pengambilan data. Kecepatan angin pada ketinggian gedung sekitar $7 \mathrm{~m}$ dari permukaan tanah tidak mencapai 5 knots, hal ini wajar karena pengaruh dilingkungan sekitar yang banyak terdapat gedung dan tidak terjadi hujan pada saat itu.

\section{KESIMPULAN}

Pada penelitian ini telah dirancang sistim pengamat cuaca menggunakan beberapa parameter fisis seperti suhu, kelembaban, tekanan udara, iluminasi dan kecepatan angin. Dari data pengujian didapatkan nilai selisih pembacaan $0 \mathrm{~s} / \mathrm{d} 0.5^{\circ} \mathrm{C}$ untuk parameter suhu dengan nilai error maximum $1.76 \%$ dan error minimum $0 \%$. Nilai selisih pembacaan $3 \%$ $3.5 \%$ untuk kelembaban dengan nilai error maximum $4.3 \%$ dan error minimum $2.5 \%$ 
dari selisih pembacaan. Pada pengujian parameter tekanan udara selisih pembacaan $0.1 \mathrm{hPa}$ dengan nilai erorr dari selisih pembacaan terbesar $0.0099 \%$ dan terkecil $-0.0099 \%$. Selisih pembacaan $0.22-0.55$ knots untuk kecepatan angin dengan nilai error maksimum $21.6 \%$ dan error minimum, $-26.7 \%$. Dan nilai error rata-rata $-1.5 \%$ untuk Iluminasi, dengan error terbesar yang diperoleh adalah 5.3\%.

Dan pada saat pengambilan data, hasil dari data yang ditampilkan sesuai dengan gejala fisis yang terjadi di lingkungan sekitarnya. Maka dapat disimpulkan sistim yang terbentuk telah dapat membaca dan mengirimkan data ke PC dengan menggunakan wireless. Sistim ini dapat berjalan dengan konsumsi daya rendah berkisar 2V dalam waktu 11 jam. Data tersebut tersimpan secara otomatis ke database MySQL dengan aplikasi VB.Net, dengan tampilan berupa Graphical User Interface yang dapat mempermudah pengamat dalam mengamati cuaca. Data akan dapat dilihat sewaktu-waktu apabila diperlukan. Data yang diterima pada receiver membutuhkan waktu $30 \mathrm{~s} / \mathrm{d} 56$ detik dari alat pada bagian transmitter.

\section{DAFTAR PUSTAKA}

[1] Rizki Mahmudah, Sistem pemantauan Cuaca Berbasis Mikrokontroler H8. Depok: UI, 2012.

[2] Peter Berlin, The Geostationary Applications Satellite. Inggris: Cambrigde University Press, 2004.

[3] Mustofa, Meteorologi dan Klimatologi. Pontianak: STKIP PGRI, 2011.

[4] Eko Triraharjo, Cut Meurah Regariana, Cuaca dan Iklim. Jakarta, 2005.

[5] M. Syarif Hidayat, Unsur-Unsur Iklim. Malang: UMB, 2013.

[6] Arief Hendra Saptadi, "Perbandingan Akurasi Pengukuran Suhu dan Kelembaban Antara Sensor DHT11 dan DHT22," vol. 6 No.2, 2014.

[7] Aosong Electronics Co, "Temperature and Humidity Module AM2302," Guangzhou.

[8] Bosch Sensortec, "Data sheet BMP180 Digital Pressure Sensor," BST-BMP180DS000-09, 2013.

[9] Aldi Agustian, Rancang Bangun Miniatur Stasiun Cuaca Berbasis Mikrokontroller. Depok: Universitas Indonesia, 2009.

[10] Nurhamidah Rizki Lubis, Alat Ukur Kecepatan dan Arah Angin Berbasis Mikrokontroler Atmega16A. Medan: Universitas Sumatera Utara, 2014.

[11] Andriani Nirwana Barus, Alat Ukur Intensitas Cahaya dengan Menggunakan LDR Berbasis Mikrokontroler ATMEGA8. Medan: Universitas Sumatera Utara, 2014.

[12] Feranita dan Hendra Surya Ery Safrianti, "Perancangan Alat Ukur Kecepatan dan Arah Angin," Jurnal Rekayasa Elektrika Vol. 9, No. 1, pp. 30-35, April 2010.

[13] Tumiar Katarina Manik, Klimatologi Dasar;Unsur Iklim dan Proses Pembentukan Iklim. Yogyakarta: Graha Ilmu, 2014. 